\title{
„Niemowa z Kampen” - Hendrick Avercamp w Archiwum Zbigniewa Herberta
}

Opracowany przez Barbarę Toruńczyk nieukończony szkic Zbigniewa Herberta De stomme van Kampen (1585-1643) po raz pierwszy ukazał się w „Zeszytach Literackich” w roku 1999². Opatrzono go mylącym komentarzem:

Destomme van Kampen (1585-1643). W tymże dossier, osobno, notatki, rękopis i maszynopis (kopia na przebitce formatu A4, 5 kartek nienumerowanych z odręcznymi poprawkami Z.H. piórem, długopisem, ołówkiem i zabielaniem) ukończonego szkicu, zatytułowanego w rękopisie Malarz czwartej pory roku. Hendrick Avercamp (1585-1634), a w maszynopisie Destomme van Kampen (1585-1643). Rękopis na odwrocie druków oficjalnych z datami: 1983, 19873; notatki na druku z datą „24. Feb. 1969”. Pierwsza strona maszynopisu przekreślona do słów „Nic nie da się powiedzieć o jego wewnętrznym dojrzewaniu i przemianach" powtarza się we wszystkich wersjach rękopiśmiennych. Przytaczamy w całości [podkr. - M.Ś.]4

Czytelnicy zostali dwukrotnie wprowadzeni w błąd. Po pierwsze, nieprawdziwa jest informacja, jakoby esej De stomme van Kampen był tekstem zamkniętym, ostateczną wersją przygotowywanego przez Herberta utworu. Po drugie, szkic opublikowany w „Zeszytach Literackich” nie jest drukowany w cało-

I Artykuł powstał w ramach promotorskiego projektu badawczego „Polska literatura powojenna wobec malarstwa holenderskiego złotego wieku” (N N103 059338), którym kieruje prof. dr hab. Agata Stankowska.

2 Z. Herbert, De stomme van Kampen (1585-1634), „Zeszyty Literackie” 1999, nr 4, s. 11-14.

3 Rękopis znajduje się na drukach z datami 1978-1983, nigdzie nie pojawia się rok 1987.

4 Odwydawcy, „Zeszyty Literackie” 1999, nr 4, s. 27. 
ści, o czym świadczą wersje rękopiśmienne, w których pojawiają się dalsze partie utworu.

Esej przedrukowano następnie w 2008 r. w tomie „Mistrz $z$ Delft" $i$ inne utwory odnalezione ${ }^{5}$. W dołączonej od wydawcy części Komentarze i objaśnienia odnajdujemy krótką, podobną do wcześniejszej, notkę. Tym razem jednak nie pojawiają się sformułowania świadczące o tym, że publikowany szkic jest ostateczną wersją, a więc utworem pełnym, ukończonym. Wręcz przeciwnie, Toruńczyk stara się dowieść - rewidując wcześniejsze ustalenia - że De stomme van Kampen jest tekstem niegotowym i niekompletnym, swoistym dziełem w toku:

De stomme van Kampen (1585-1634). Z teki Martwa natura. Mali mistrzowie. Przytaczamy z pięciostronicowej kopii maszynopisu z nielicznymi poprawkami Herberta. Na innej kopii tego samego maszynopisu widnieją liczne odręczne poprawki Herberta, skreślenia oraz obszerne dopisane fragmenty, świadczące o zamiarze przeredagowania tekstu. Rękopis szkicu przechowywany w tej samej tece nosił tytuł: Malarz czwartej pory roku. Hendrich [sic!] Avercamp (1585-1634). Z dat widniejących na drukach, na których odwrocie Herbert spisał niniejszy szkic, wnosimy, że powstał on w latach $80 .{ }^{6}$

Podane informacje są bardzo zdawkowe. Dowiadujemy się, co prawda, że Herbert cały czas pracował nad tekstem (pozostawił wszak maszynopisy z odręcznymi poprawkami), że zmieniał poszczególne fragmenty, ale nie wiemy, jakie partie planował przeredagować, co dopisał, jak wyglądała wersja eseju o Hendricku Avercampie pozostawiona w rękopisie. Toruńczyk udostępniła czytelnikom nieznane dotąd szkice (co ma oczywiście dużą wartość popularyzatorską), nie opatrzyła ich jednak rzetelnym komentarzem, czyniąc w ten sposób z tekstów zebranych w tomie „Mistrz z Delft” $i$ inne utwory odnalezione kanoniczne warianty nieukończonych esejów o malarzach holenderskich złotego wieku. Podkreślić należy więc arbitralność decyzji o wyborze zarówno konkretnej wersji tekstu o Avercampie, jak i tytułu.

Materiały dotyczące Avercampa, dostępne w Archiwum Zbigniewa Herbertazdeponowanym w Bibliotece Narodowejw War-

5 Z. Herbert, De stomme van Kampen (1585-1634), w: „Mistrz z Delft” i inne utwory odnalezione, oprac., komentarz B. Toruńczyk, współpraca H. Citko, Warszawa 2008, s. 43-47.

${ }^{6}$ B. Toruńczyk, Komentarze i objaśnienia, w: ibidem, s. 189. 
szawie, znajdują się w teczce o sygnaturze akc. 17854 t. 137, fragment rękopisu znaleźć można również w teczce o sygnaturze akc. 17849 t. $4^{8}$. Esej o Avercampie miał wejść do planowanego przez Herberta drugiego tomu esejów na temat XVII-wiecznej Holandii, któremu poeta chciał nadać tytuł (lub podtytuł) Mali mistrzowie. W Archiwum niejednokrotnie odnajdujemy notatki świadczące o tym, że Herbert projektował spis treści kolejnego zbioru szkiców o kulturze holenderskiej złotego wieku. Wśród „małych mistrzów” pojawia się oczywiście nazwisko (lub pseudonim) artysty z Kampen ${ }^{9}$.

\section{Kwestia tytułu}

Już na samym początku napotykamy istotną trudność związaną z ustaleniem tytułu szkicu o Avercampie. Redakcja „Zeszytów Literackich" zdecydowała, że udostępniony czytelnikom esej, drukowany z nieukończonego maszynopisu, zostanie opublikowany jako De stomme van Kampen (1585-1634). Istnieje jednak druga wersja tytułu: pozostawioną w rękopisie, najdłuższą wersję tekstu Herbert zatytułował Malarz czwartej pory roku. HENDRICK AVERCAMP. Drugi tytuł zostaje wprawdzie przez Toruńczyk wspomniany w Nocie od wydawcy i Komentarzach i objaśnieniach ${ }^{\text {To }}$, ale nie pojawia się adnotacja, że dwa warianty szkicu - rękopis i maszynopis ${ }^{\text {II }}$ - znacząco się różnią.

Oba tytuły przynoszą ważne informacje. Pierwszy odsyła do faktu rzeczywistego upośledzenia malarza: „de Stom[me] van Kampen” należy bowiem tłumaczyć jako „Niemowa z Kampen”. Jonathan Bikker w artykule Hendrick Avercamp. „The Mute of Kampen” wskazuje na istniejące dowody ułomności artysty: „Jednym z dokumentów odkrytych przez Nanninga Uitterdijka była petycja matki Avercampa z 1633 roku, by przyznano jej synowi coroczną zapomogę. W petycji tej nie tylko nazwała swojego najstarszego syna «niemową» $[$ stom], ale również «nie-

7 Archiwum Zbigniewa Herberta. Inwentarz, oprac. H. Citko, Warszawa 2008, s. 37: „Martwa natura z wędzidtem. T. 13. Materiały różne (Mali mistrzowie). Notatki do planowanego szkicu o Hendricku Avercampie. Z teki opisanej «Martwa natura. Mali mistrzowie»".

${ }^{8}$ Ibidem, s. 25-26: „Epilog burzyt. 4 [...] 39. Fragment (całość); na odwrociu fragment szkicu o Hendricku Avercampie”.

9 Warto podkreślić, że w sporządzonych przez Herberta spisach treści nie zawsze występuje ten sam zestaw nazwisk.

то Odreydawcy, s. 27; Komentarze iobjaśnienia, s. 189.

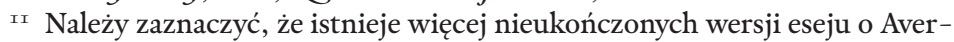
campie, pozostawionych w rękopisach i maszynopisach. 
szczęsnym» [miserabel]" ${ }^{\mathrm{I} 2}$. Badacz podkreśla, że nie powinniśmy mieć wątpliwości, iż chodzi o prawdziwy fizyczny defekt, a nie o metaforyczne sformułowanie: „matka Avercampa, opisując go, posłużyła się słowem «niemowa», oczywiście nie użyła tego jako przydomka, będącego aluzją do jego «milczącej natury i skromności»" ${ }^{23}$. Tego samego zdania jest Herbert:

Nosił za życia przydomek „de stomme van Kampen” - co należy rozumieć dosłownie jako niemowa z Kampen, i nie ma w tym żadnego szyderstwa, tylko rzeczowe stwierdzenie kalectwa [- i nazwisko malarza -], tak jak innych nazywano [mówiono] „kulawy”, "garbus” czy obłąkany. $(\mathrm{AZH})^{\mathrm{I}}$

Z kolei drugi tytuł, którym Herbert opatrzył rękopis Malarz czwartejpory roku. HENDRICKAVERCAMP, jest wyraźną aluzją do faktu, że w XVII w. pejzaż zimowy usamodzielnił się jako gatunek malarski, a Avercamp uznany został za jego holenderskiego kodyfikatora:

upodobanie do lodu nigdy nie zostało lepiej wyrażone niż na obrazach i rysunkach Hendricka Avercampa. Wkrótce po roku 1600 uczynił on „sceny lodowe” pełnoprawnym gatunkiem. Był pierwszym artystą, specjalizującym się w malowaniu pejzaży zimowych, przedstawiających ludzi czerpiących przyjemność z zabaw na lodzie ${ }^{15}$.

Historycy sztuki są zgodni, że rola Avercampa w ukonstytuowaniu się pejzażu zimowego jako odrębnego gatunku jest niekwestionowana: „Zaszczyt bycia pierwszym północnoniderlandzkim artystą, malującym pejzaże zimowe z ludźmi czerpiącymi przyjemność z zabaw na lodzie, przypadł Hendrickowi Avercampowi (1585-1634), którego najwcześniej datowany ob-

I2 J. Bikker, Hendrick Avercamp. „, The Mute of Kampen”, w: Hendrick Avercamp. Master of Ice Scene, red. P. Roelofs et al., Amsterdam 2009, s. 12.

I3 Ibidem, s. 11.

I4 Fragmenty pochodzące z Archiwum Zbigniewa Herberta oznaczam skrótem AZH. W cytatach poprawiam literówki, odstępstwa interpunkcyjne i ortograficzne. Dopiski Herberta, znajdujące się na marginesach bądź nad tekstem głównym, umieszczam w nawiasach kwadratowych. Ukośnik oznacza, że nad tekstem bądź na marginesach znajdowały się notatki, które albo były kilkoma wariantami wprowadzonych przez poetę poprawek, albo nie stanowiły spójnej całości - zdecydowałam się zatem graficznie je rozdzielić. Wszelkie przekreślenia i podkreślenia pochodzą od Herberta.

${ }_{5}$ W. Pijbes, E.A. Powell III, Foreword, w: Hendrick Avercamp..., s. 7. 
raz pochodzi z 1608 roku” ${ }^{{ }^{6}}$. Nie należy jednak zapominać, że krajobrazy zimowe mają swoją długą tradycję ikonograficzną. Genezę obrazów Avercampa wywodzi się bezpośrednio z pejzaży zimowych, powstających w XVI-wiecznej Flandrii:

formacyjny wpływ na jego [Avercampa] twórczość miała tradycja pejzażu flamandzkiego, którą musiał studiować przede wszystkim za pośrednictwem rycin według kompozycji Pietera Bruegla, Hansa Bola i Davida Vinckboonsa. Mur browaru na lewym skraju wielkiego obrazu Avercampa z Rijksmuseum jest ozdobiony antwerpską tarczą herbową, podtrzymywaną przez dwa heraldyczne lwy, co interpretowane jest jako hołd dla źródła jego inspiracji. Widoczna na pierwszym planie po lewej stronie pułapka na ptaki stanowi odwołanie do dobrze znanego Pejzażu zimowego z byżwiarzami i pulapka na ptaki Bruegla, skąd najprawdopodobniej została zapożyczona. [...] Uniezależnił się, kiedy powrócił do Kampen, rozwijając holenderski wariant pejzażu zimowego ze sportami na lodzie ${ }^{\mathrm{I}}$.

Istotny $-\mathrm{z}$ punktu widzenia tezy o wpływie południowoniderlandzkiej tradycji pejzażu na twórczość Avercampa - szczegół (herb Antwerpii) nie umknął uwadze Herberta. W poświęconej Avercampowi teczce odnajdujemy zdawkową notatkę: „flamandzka atmosfera - herby [miejskie godła] Antwerpii na gospodzie” $(\mathrm{AZH})$. Poeta nie waha się stawiać pytań o źródła malarskiego idiomu „Niemowy z Kampen”. Jako ważny punkt odniesienia wskazuje technikę „dawnych mistrzów”, ich sposób posługiwania się kolorem oraz stosunek do portretowanych rzeczy:

Bardziej prawdopodobne jest przypuszczeń, że swoją Farbenlebre czerpał ze źródeł malarstwa flamandzkiego (albo co najmniej) za pośrednictwem [malarzy]-emigrantów [z południa] flamandzkich - malarze, którzy przybyli do wolnej Holandii. Dawna sztuka Van Eycka, Memlinga, Goesa nie umarła [W sztuce Avercampa odzywa się echo dawnych mistrzów Van Eycka, Memlinga, Goesa]. Zmieniły się konwencje sztuki, style, tematy, kręgi odbiorców [niemal wszystko]. Mistrz z Kampen nawiązuje wyraźnie do czegoś, co określa się jako materię malarską, do zamieniania [olejnej] farby w przedmioty stałe, mające konsystencję [substancjalność] minerałów, klejnotów, szlachetnych kamieni, twardość, odporność,

${ }^{16}$ Holland Frozen in Time. The Dutch Winter Landscape in the Golden Age, red. A. van Suchtelen, współpraca F.J. Duparc, P. van der Ploeg, E. Runia, Zwolle 2006, s. 50.

I7 Ibidem, s. 52. 
a jednocześnie przejrzystość, zdolność odbijania i pochłaniania światła. (AZH)

Dążenie „dawnych mistrzów” do uobecniania malowanych przedmiotów, nadawania substancjalności przedstawieniu, poeta nazywa „materią malarską”. Skonstruowana przez niego definicja tej praktyki przywodzi na myśl fragment wiersza Dawni Mistrzowie: „powierzchnie ich obrazów/ są gładkie jak lustro” ${ }^{18}$, wydaje się eseistyczną parafrazą tego dwuwersu. Jednak najbardziej wyraźnym i oczywistym tropem, na który naprowadza nas Herbert, gdy stara się zrekonstruować artystyczną drogę Avercampa, jest oczywiście twórczość Pietera Bruegla Starszego.

\section{Avercamp - Bruegel (i flamandzka tradycja pejzażu)}

Dostrzeżone przez Herberta podobieństwo scen zimowych Avercampa do malarstwa Bruegla, przede wszystkim zaś słynnego Pejzazu zimowego z byzwiarzami i pułapka na ptaki, jest analogią, która nasuwa się od razu. Nic dziwnego, że porównanie dzieł obu pejzażystów - południowo- i północnoniderlandzkiego, XVI- i XVII-wiecznego pojawia się w większości prac poświęconych Avercampowi:

Pejzaż zimowy z Wiednia i Pejzaż zimorey ze ślizgareka seum, oba dowodzą ogromnego długu, jaki artystazKampen zaciagną̧ u Bruegla we wczesnym etapie swojej twórczości. Na tym ostatnim obrazie panoramiczna perspektywa, wysoki horyzont, wzniesienia w oddali, jasny koloryt lokalny, narracyjny charakter i obfitość detali przejęte są bezpośrednio od jego flamandzkiego poprzednika ${ }^{20}$.

Nieulega wątpliwości, że najistotniejszym miejscem wspólnym w twórczości obu artystów jest pułapka na ptaki: „Najosobliwszą analogią między obrazami Avercampa a dziełem Bruegla jest pułapka na ptaki. Pułapka ta, wykonana ze starych drewnianych drzwi, jest jednym z najbardziej uderzających motywów w Pejzażu zimowym z byzwiarzami i pułapka na ptaki Bruegla" ${ }^{21}$. Porównanie Herberta nie opiera się jednak na wyliczeniu powtarzających się motywów albo odnajdywaniu podobnych szczegółów.

I8 Z. Herbert, Dawni Mistrzowie, w: Poezje, Warszawa 1998, s. 447.

I9 $\mathrm{W}$ artykule używam jednego z zaproponowanych przez Herberta thumaczeń tytułu słynnego amsterdamskiego pejzażu Avercampa.

${ }_{20}$ Hendrick Avercamp..., s. 34-35.

${ }^{21}$ Ibidem, s. 35. 
Poeta stara się raczej zestawić dwie koncepcje ontologiczne, dwa sposoby podejścia do rzeczywistości, dwie malarskie optyki:

[Jaka jest] Wizja świata [Avercampa?] (czy, mówiąc górnolotnie, filozofia tych płócien) na pierwszy rzut oka przypomina wielkiego Breugla - bezsenso absurdalna ruchliwość ludzkich atomów pośród obojętnej przyrody. (AZH)

Wydaje się, że Herbert celowo rezygnuje z konfrontacji „inwentarza" obu pejzaży zimowych, ponieważ mogłaby doprowadzić go do stwierdzenia zbyt łatwo narzucających się analogii. Warto pamiętać, że poeta dąży do tego, by pokazać swoistość dzieła Avercampa, przedstawić artystę, który mówi (a właściwie milczy) innym głosem:

Avercamp nie jest fragmentem [częścia] wielkiej epopei holenderskiego malarstwa, ale stanowi zjawisko odrębne i zamknięte. Dlatego jest zapewne mało wdzięcznym tematem [obiektem badań] tha tyeh, którzy trakttują historię sztuki w sposób raejonalny zwłaszcza dla tych, którzy sprawy artystyczne [dzieje sztuki] ujmują w związki przyczynowo-skutkowe [gdzie jedno z drugiego musi koniecznie wynikać] i tropią logiezne następstwo [wplyw, następstwa]. Dlatego łatwo daje się zepchnąć na margines. (AZH)

$\mathrm{Z}$ tego powodu bardziej niż podobieństwa interesują pisarza różnice między malarskimi idiomami niderlandzkich mistrzów. Herbert konfrontuje dwie, jego zdaniem niesprowadzalne do siebie, wizje świata:

Bruegel a Avercamp.

Bruegel - pejzaż kosmiczny, wyrażający znikomość człowieka, jego bezsensowną krzątaninę, lekkomyślny „taniec pod szubienicą”.

Avercamp - pejzaż oswojony, godny zamieszkania, w którym miniaturowe postacie [daleki pejzaż / malowane nie z wyżyn filozofa, ale po prostu z wieży kościelnej] obserwowane są z sympatią, bez cienia sarkazmu czy ironii, bez posępnej refleksji nad nicością rzeczy i znikomością ludzkiej egzystencji, i to właśnie, owa akceptacja świata, jest bardzo holenderska. (AZH)

Herbert stara się przedstawić Avercampa jako malarza prostodusznego, głoszącego przez swoje płótna pochwałę stworzenia. Avercamp - zdaje się mówić Herbert - wierzy, że świat został stworzony dla człowieka, który dąży do tego, by czerpać przyjemność z ziemskiego życia. W takiej perspektywie pejzaże 
Bruegla (mimo wielu zbieżności) okazują się zupełnym zaprzeczeniem kompozycji Avercampa. Nawet znaczenie wysokiego punktu obserwacyjnego, który przez historyków sztuki traktowany jest jako jeden z elementów przejętych od Bruegla, zostaje przez Herberta zrewidowane i służy ukazaniu różnic między tymi dwiema koncepcjami sztuki. Ptasia perspektywa - zdaniem poety - jest u Bruegla sposobem wzniesienia się ponad ludzką krzątaninę, wskazania na przemijalność egzystencji, a maleńkie postaci są figurami na szachownicy świata; u Avercampa zaś zauważa tylko „malowanie [...] z wieży kościelnej”, próbę udokumentowania rzeczywistości. Pochylający się nad światem Bruegel to artysta snujący gorzką refleksję nad losem człowieka. Pochylający się nad światem Avercamp to artysta pogodnie spoglądający na poczynania swoich współziomków.

Pozostaje jeszcze pytanie, w jaki sposób Avercamp zetknął się z twórczością swego flamandzkiego „poprzednika”. Jest wiele elementów na płótnach Avercampa świadczących o dobrej znajomości tej tradycji. Avercamp mógł spotkać się z nią za pośrednictwem powszechnych wówczas kopii ${ }^{22}$ lub rycin:

Słynne obrazy Bruegla musiały być dobrze znane dość szerokiej publiczności za sprawą kopii, malowanych w dużych ilościach, ale dla rozpowszechnienia tej sztuki ważniejsze nawet okazały się grafiki, wykonywane według jego kompozycji, rozprzestrzeniające się dzięki licznym edycjom ${ }^{23}$.

Duży udział miały w tym ryciny Hansa Bola: „To częściowo dzięki grafikom według kompozycji Bola wiele motywów, mających swoje źródło w oeuvre Bruegla, trafiało do dzieł artystów takich jak David Vinckboons, Adriaen van de Venne i Hendrick Avercamp" ${ }^{24}$. Podejmowane przez historyków sztuki próby ustalenia malarskich wpływów często kończą się sukcesem. Ikonograficzna tradycja, do której odwoływał się Avercamp, została bardzo dokładnie opracowana. O Avercampie artyście można powiedzieć znacznie więcej niż o Avercampie człowieku. Także Herbert miał świadomość istnienia wielu pustych miejsc w biografii „Niemowy z Kampen”. Nie można zapominać, że pisarz nie tylko poszukiwał odpowiedzi na pytanie o artystyczne źródła twórczości Avercampa, ale starał się także zrekonstruować szczegóły jego życia.

${ }^{22}$ Na temat licznych kopii obrazów Bruegla zob. L'Entreprise Brueghel, red. P. van den Brink, Maastricht-Bruxelles 2001.

${ }_{23}$ Holland Frozen in Time..., s. 42.

24 Ibidem, s. 46. 


\section{Przyczynek do biografii artysty z Kampen}

Herbert doskonale zdawał sobie sprawę $\mathrm{z}$ tego, że informacje biograficzne dotyczace ukochanych przez niego „małych mistrzów” holenderskich są najczęściej bardzo ubogie. Wynotowywał zatem nawet najdrobniejsze fakty z ich życia. Stał jednak na stanowisku, że wiadomości na temat dzieciństwa, edukacji, statusu społecznego czy wykonywanego dodatkowo zawodu nie mogą zostać potraktowane jako jedyny klucz interpretacyjny do twórczości. Często zdarza się nawet, że skrupulatnie budowany przez poetę kontekst biograficzny okazuje się niemal nieprzydatny. Herbert traktuje go tyle jako podstawę odczytania oeuvre artysty, co jako barwną anegdotę. Tak jest w przypadku szkicu o Avercampie. Poeta przywołuje, zdawałoby się, istotny fakt $\mathrm{z}$ dzieciństwa malarza, po czym kwestionuje interpretacyjną przydatność tego szczegółu:

Jako młody chłopiec - kalectwo pozbawiło go zabaw z rówieśnikami - przesiadywał podobno w aptece ojca i godzinami przyglądał się słojom zawierającym różnobarwne mikstury. To historyjka jakby żywcem wyjęta z modnych dawniej vie romancée, może nawet wzruszająca, ale thumaczy mało. Dzieło jego - jedyny wiarygodny dokument - świadczy o tym, że wiedzę o kolorze i materii malarskiej zaczerpnął od starych mistrzów. (AZH)

Informacja o ojcu aptekarzu jest prawdziwa. Bikker pisze:

27 stycznia 1585 roku Barent Avercamp i Beatrix Peters w Oude Kerk w Amsterdamie ochrzcili swoje pierwsze dziecko, Hendricka, imię to odziedziczył po dziadku ze strony ojca. [...] W 1586 roku Barent przenosi się z żoną i dzieckiem do Kampen, gdzie mianowany jest miejskim aptekarzem ${ }^{25}$.

Dowiadujemy się także, że wspominana przez Herberta apteka mieściła się w domu Avercampów:

Bardzo mało wiadomo na temat faktycznych warunków życia Avercampa w Kampen. Przyjmuje się, że mieszkał ze swoją matką $\mathrm{w}$ domu przy Oudestraat, w którym znajdowała się również apteka. W każdym razie w testamencie pochodzącym z 18 grudnia 1633

25 J. Bikker, op.cit., s. 12. 
roku Beatrix Peters zapisała swojemu synowi Hendrickowi „łóżko z jego wyposażeniem w małym pokoju" ${ }^{26}$.

Na podstawie niewielu faktów próbuje się ustalić szczegóły biografii Avercampa. Niewątpliwie, co podkreśla także Herbert, „większą część życia spędził w Kampen” (AZH). Najprawdopodobniej w tym mieście namalował większość swoich dzieł: „Żadna z prac Avercampa - podkreśla Bikker - nie może być wykorzystana jako dowód jego aktywności poza Kampen” ${ }^{27}$. Herbert pisze ponadto o podwójnej prowincjonalności Avercampa. Po pierwsze, Avercamp mieszkał w mieście, które nie było ważnym ośrodkiem artystycznym; po drugie, podejmował w swojej sztuce tak zwane niskie tematy. Argumenty te pozwalają poecie na istotną konstatację: „W «prowincjonalnym» malarstwie holenderskim A. był esencją prowincjonalności” (AZH). Herbert na wiele sposobów dowodzi - rozumianej w bardzo specyficzny sposób - marginalności i osobności Avercampa.

Kolejnym potwierdzeniem odrębności i wyjątkowości Avercampa jest dla pisarza skromna recepcja jego twórczości. Poeta podkreśla, że - poza Barentem Avercampem - żadnego z malarzy nie można określić mianem ucznia Hendricka Avercampa:

Samotność pogłębiona kalectwem [osiedlenie się w miejscu pozbawionym życia artystycznego], wybór miejsca zamieszkania gdzie nie tętniło życie artystyczne sprawiły, że nie założył szkoły i w wielkiej epopei malarstwa holenderskiego stanowi zjawisko odrębne i zamknięte. [Jeśli dobrze wiem] Tylko jego siostrzeniec Barent był jego uczniem niezbyt [mało] wybitnym naśladowcą, ale przeniósł nazwisko Avercampów aż do roku 1670, kiedy dogasał „wiek złoty”, ale zyskał powodzenie, co jedni przypisują jako pracom artysty] jego obrazów, inni $[\ldots]^{28}$ dobrze prosperującym przedsiębiorstwom handlu drzewem, torfem, mąką, co dawało mu wstęp do urzędów magistrackich i prezesurę Gildii św. Łukasza. $(\mathrm{AZH})$

Obrazy Barenta Avercampa nie dorównywały płótnom jego stryja. Właśnie stryja, bo Barent był bratankiem Hendricka, a nie - jak chce Herbert - jego siostrzeńcem. Zasługą Barenta jest, według poety, podtrzymanie i przedłużenie malarskiego idiomu „Niemowy z Kampen”. Barent, co podkreślają również historycy sztuki, „przeniósł charakterystyczną tradycję Aver-

\footnotetext{
${ }^{26}$ Ibidem, s. 17.

${ }^{27}$ Ibidem, s. 16.

${ }_{28}$ Słowo nieczytelne, być może przekreślone.
} 
campa do późnych lat 60-tych XVII wieku” ${ }^{29}$, jednak nigdy nie będzie postawiony na równi ze swym mistrzem:

Last but not least, pośród malarzy w Kampen, z którymi Avercamp miał artystyczne związki, był jego bratanek Barent Avercamp (ok. 1612-1679); syn Petera, brata Hendricka, który od 1615 roku aż do swojej śmierci w 1626, był aptekarzem w pobliskim Zwolle. Po śmierci Petera Avercampa, jego żona [...] wraz z dziećmi wróciła do Kampen i to prawdopodobnie wówczas Barent terminował u swego stryja. [...] Malarstwo nie było jego jedynym źródłem utrzymania przez całe życie. Miał również inne zatrudnienia - był handlarzem drewnem, odlewał garnki. Zanim Clara Welker dokonała swego znaczącego odkrycia, dotyczącego biografii Avercampa, mianowicie, że artysta został pochowany 15 maja 1634 roku, wiele obrazów Barenta z mniej detalicznymi i mniej wytrawnymi kompozycjami oraz przysadzistymi, raczej sztywnymi postaciami, przypisywano jego stryjowi, którego talent - jak sądzono - uległ na starość rozproszeniu $^{30}$.

Potwierdzają się zatem informacje, że Barent nie utrzymywał się wyłącznie ze sprzedaży własnych dzieł. Nie ma również wątpliwości, że obrazy Barenta nie udźwignęly ciężaru tradycji, do której nawiązywały. Styl Hendricka Avercampa okazał się zbyt trudny do naśladowania. Być może dlatego „Niemowa z Kampen" nie znalazł licznych kontynuatorów. Herbert podkreśla, że XVII-wieczny pejzaż holenderski rozwinął się w innym kierunku:

Wielcy pejzażyści holenderscy nie powoływali się na Avercampa rozwój tego kierunku [rodzaju] malarstwa, wsparty wielkimi talentami poszedł w zupełnie innym kierunku niż dzieło „głuchego z Kampen”. Mało da się powiedzieć o jego rozwoju wewnętrznym, dojrzewaniu i przemianach. Pierwszy datowany obraz z roku 1608 (artysta miał wówczas dwadzieścia trzy lata) jest równie mistrzowski jak dzieła późniejsze. Zachwycający dla laika, jest chyba mało wdzięcznym obiektem badań i dociekań naukowych. (AZH)

Na uwagę zasługuje jeszcze jeden szczegół biograficzny. Wiemy - dzięki odnalezionym dokumentom - że artysta był niemy. Dlaczego więc Herbert nazwał go nagle „głuchym z Kampen”? Czy to zwykła - wcale nie tak rzadko pojawiająca się w notatkach poety - pomyłka?

29 Holland Frozen in Time..., s. 58.

$3^{\circ}$ J. Bikker, op.cit., s. 19-20. 
Podobne określenie odnajdujemy również w jednym z rękopisów Herberta: „[Za życia, a i potem także] Nazywano go de Stomme van $\mathrm{K}[\mathrm{C}]$ ampen (Jego niemota i zapewne gltrehota) Nie jest rzeczą przyzwoitą wywodzić sztukę z kalectwa artysty. [Ale było to zapewne nie jakieś prześmiewcze przezwisko, ale określenie ułomności fizycznej]” (AZH). Przekreślony przez poetę fragment świadczy o tym, że Herbert użył słowa „głuchy” nieprzypadkowo. Musiał zatem dotrzeć do opracowań, w których stawiano tezę, że Avercamp był głuchoniemy. Wiemy, że wielu historyków sztuki zastanawiało się nad tym, czy malarz był tylko niemy, czy także głuchy:

Podczas gdy nie mamy wątpliwości, że Avercamp był niemy, w żadnym z dotychczas odkrytych dokumentów nie nazywa się go głuchym. Opinie historyków sztuki są podzielone, utrzymywano, że był głuchy, ponieważ niemota jest zwykle spowodowana głuchotą, inni zwracali uwagę, że nie ma żadnych dowodów, pozwalających na wyciągnięcie takich wniosków ${ }^{31}$.

Trudno jednoznacznie stwierdzić, jaką hipotezę stawia Herbert. W notatkach poety znaleźć można jeszcze jeden dowód na to, że miał on zamiar rozważyć prawdopodobieństwo istnienia drugiej, obok niemoty, fizycznej ułomności Avercampa. W skonstruowanym przez poetę planie eseju o holenderskim „małym mistrzu” pojawia się w punkcie szóstym (i zarazem ostatnim) słowo „głuchy”:

1) Obrazy do czytania, z szeregiem anegdotą

2) wizja świata (konieczna wycieczka w dziedzinę kostiumologii)

nie są to doskonałe twory

mrówcza absurdalna ruchliwość ludzkich $[\ldots]^{32}$ pośród obojętnej przyrody

kontrast między materią a

3) kolory $\rightarrow$ kamień

horyzont - głębia

niebo i śnieg

4) świat wklęsły / kulisty / [słowo nieczytelne]

5) głuchy naiwność

6) głuchy. (AZH)

\footnotetext{
${ }^{3}$ I Ibidem, s. 20.

$3^{2}$ Słowo nieczytelne.
} 
Kwestia rzeczywistego upośledzenia artysty musi na tym etapie dociekań pozostać nierozwikłana. Herbert w znajdujących się w Archiwum wariantach szkicu o „Niemowie z Kampen” nie rozwija enigmatycznie zapowiedzianej cząstki „głuchy”. Zapisany przez poetę układ poszczególnych partii tekstu jest jeszcze bardziej zagadkowy, ponieważ żadnego $\mathrm{z}$ nieukończonych rękopisów i maszynopisów eseju nie można potraktować jako dokładnej realizacji tego planu, który - jak sądzę - nie jest ostateczną wersją konspektu. Poeta zostawił przecież niedokończone myśli, zmieniał kolejność przewidywanych fragmentów - nie da się więc w pełni zrekonstruować ostatecznego zamysłu kompozycyjnego. Co ciekawe, Herbert nie ujął bezpośrednio w swoim planie jednego z najistotniejszych elementów eseju - rozbudowanego opisu najsłynniejszego zimowego pejzażu Avercampa.

\section{Pejzaż zimowy ze ślizgawka - ćwiczenia z ekfrazy}

Herbert najprawdopodobniej nie zamierzał przybliżyć czytelnikom wielu płócien Avercampa. W rękopisach i maszynopisach najczęściej pojawia się tylko jeden obraz „Niemowy z Kampen”, słynny Pejzaż zimowy ze ślizgareka (ok. 1608) z Rijksmuseum. Można jednak odnaleźć nieliczne i dość zdawkowe fragmenty poświęcone innym pejzażom Holendra. Dwukrotnie przywoływany jest Krajobraz zimowy z byzwiarzami (ok. 1608) z National Gallery w Londynie. Herbert wspomina o nim, kiedy stara się dowieść, że wykreowana przez Avercampa rzeczywistość rządzi się własnymi prawami:

Ten malarz [holenderski] pozwala żyć światu tak jak mu się podoba, jak rzece pełnej zakrętów i wirów. [...] W Krajobrazie zimoreym $z$ byzwiarzami w National Gallery pośrodku lodowiska fantazyjny zamek zbudowany raczej do uciech zimowych niż krwawyeh [niż zapasów wojennych]. (AZH)

Poeta ponownie przywołuje londyńskie tondo, by uzasadnić tę samą tezę, tym razem jednak obok Krajobrazu zimowego z byzwiarzami wymienia inne płótna:

Krajobraz zimowy z byzwiarzami w National Gallery, przykuwający, piękny, kolisty, w środku kompozycji ma zamek, który Bóg wie [dla]czego odczytano jako symbol holenderskiego hartu ducha, choć jest on przytulny, z móstwem [bezbronny], zbudowany $\mathrm{z}$ dobrotliwej fantazji [z grubą basztą], a w dodatku przylgnęly do 
niego drewniane przybudówki. Po lewej stronie „wiedeńskiego” Avercampa przysłaniają trzy ogromne drzewa [dęby], spotykające się niemal gałęziami z drzewami po lewej stronie. Między nimi [potężnymi pniami] rozwalone płotki, łodzie, drabiny, beczki, walące się budki rybaków, wielkie koła od wozów, słowem, rustykalny bałagan. Koloński [kompozycja workowata] Avercamp, także z zamkiem pośrodku [wodzi oczy widza po zamarzniętej / zamarznięta fosa w kształcie nieregularnego owalu, przez którą przerzucone są mostki i kładki; od fosy odchodzą dwa kanały, ginące na horyzoncie] i ślizgawką, która ma kształt nieregularnego owalu, z którego prowadzą dwie odnogi. (AZH)

Zarówno wiedeński Pejzaż zimowy, jak i znajdujący się w Kolonii Pejzaż zimowy z zamkiem na wyspie należą do najwcześniejszych obrazów Avercampa, datowane są mniej więcej na rok 1605. Dzieła te pojawiają się u Herberta niejako na marginesie głównego toku narracji. Jeśli weźmie się pod uwagę kompozycję szkicu o „Niemowie z Kampen”, za centralny element dokładnie przemyślanej całości można uznać ekfrazę amsterdamskiego Pejzażu zimowego ze ślizgawka. Nic więc dziwnego, że Herbert, pracując nad esejem, wielokrotnie przeredagowywał fragment, w którym pojawia się ten pejzaż. Poeta stworzył różne wersje literackiego opisu płótna Avercampa. Różnorodność idzie w parze z wariantywnością tłumaczenia tytułu amsterdamskiego płótna. W rękopisach, maszynopisach i notatkach figuruje ono jako: Pejzaz zimowy ze ślizgawka, Krajobraz zimowy z byziwiarzami oraz Wielka scena zimowa [zimowy obraz]. Gdy czyta się stworzony na potrzeby szkicu opis, odnosi się wrażenie, że Herbert wykorzystał cały swój poetycki warsztat, że pozwolił zadziałać - odpowiednio oczywiście kiełznanej - wyobraźni. Kolejne wersje skrupulatnej relacji z tego, co zostało przedstawione na obrazie, potraktować można jako rodzaj literackich prób mierzenia się z dziełem sztuki, jako ćwiczenia z ekfrazy.

Opis Pejzażu zimowego ze ślizgawką w najdłuższym rękopisie zatytułowanym Malarz czwartej pory roku... rozpoczyna się od silnie zmetaforyzowanego fragmentu stanowiącego podstawę rozbudowanego porównania:

Wielki Pejzaż zimowy ze ślizgawką $\mathrm{w}$ amsterdamskim Rijksmuseum rozpoczyna mała uwertura brązów (dolna partia obrazu, topniejący śnieg zmieszany z ziemią [gliną], grube pnie drzew, narzędzia rozrzucone w nieładzie). Jeśli spojrzymy na malowidło z odległości zacierającej szczegóły, Pejzaż sprawia wrażenie nadwątlonego przez ogień starego rękopisu. (AZH) 
W innym miejscu Herbert jest nieco bardziej oszczędny. Powtarzają się jednak dwa motywy: „mała uwertura brązów” i porównanie do „starego rękopisu” - wcześniej nadpalonego, teraz poplamionego:

Oto Krajobraz zimowy z byziwiarzami (w amsterdamskim Rijksmuseum) rozpoczyna się [w dolnej partii/ licząc od dolnej partii] małą uwerturą brązów w dolnej części [partii] jak stary rękopis splamiony i wytarty na brzegach. (AZH)

Kolejny rękopis przynosi jeszcze mniej skomplikowaną wersję, w której Herbert zrezygnował z poetyckich konceptów, decydując się na proste, bardzo dosłowne, jednoznaczne określenie kolorystyki interesującej go części obrazu:

Spójrzmy na Wielka scenę zimowa [zimowy obraz] znajdującą się w [amsterdamskim] Rijksmuseum Amsterdamie [obraz zaczyna się w tonacji brązowej]. (AZH)

$\mathrm{Na}$ koniec spójrzmy na cytat pochodzący z opublikowanego maszynopisu. Sposób obrazowania przypomina metaforykę najdłuższego rękopisu. Fraza jest jednak dużo bardziej opanowana, czy - lepiej rzec - powściągliwa:

Oto Krajobraz zimowy z byzwiarzami w amsterdamskim Rijksmuseum. Od dołu obraz zaczyna się małą uwerturą brązów - na brzegu podobny do nadwątlonego przez ogień starego rękopisu33.

Największe zdziwienie pojawia się wówczas, gdy porównamy dalszą część ekfrazy pochodzącej z rękopisu Malarz czwartej pory roku... $\mathrm{z}$ fragmentami, które pojawiają się $\mathrm{w}$ innych wersjach nieukończonego eseju o „Niemowie z Kampen”:

Po prawej ${ }^{34}$ fragment domu z pofałdowanym wą̧sim dachem, który rośnie niemal pionowo w górę jak żagiel. Stary dom jest oswojonym żaglowcem osiadłym $\mathrm{w}$ [na] ziemi, przycumowanym do niej przy pomocy schodków, płotów, przybudówek. Przyglądam mu się z uwagą, domyślam się jego wnętrza - wielkiej kuchni z lśniącymi garnkami i rozległej izby z kominkiem, w której zbiera się rodzina, i skąd prowadzą kręte schody ku mrocznym pokojom na górze,

33 Z. Herbert, De stomme van Kampen..., s. 46.

34 Herbert niekonsekwentnie stosuje rozróżnienie na prawą i lewą stronę obrazu. W tym przypadku nie przyjmuje zwyczajowej perspektywy widza stojącego naprzeciw płótna, ale odwróconego tyłem do przedstawienia. 
schowkom, komórkom, przepaścistym strychom, gdzie gnieżdżą się duchy opiekuńcze, nietoperze i zbłąkane dusze. Dom żyje. Oddycha. Przeciąga się. Budzi. Zasypia. Opada przez sen.

Tuż obok browar, bursztynowo ciepły, z zaciekami rdzawej czerwieni, rozłożysty, wybujały, przypomina raczej ciasto uciekające $\mathrm{z}$ formy niż dzieło budowniczego. Avercamp ma wyraźną predylekcję do asymetrii i ukazywania kształtów w przestrzeni nie całkiem zgodnego z naszymi nami i schematami widzenia. Oto browar najwyraźniej staje dęba - linia prosta wykreślona wzdłuż gớrnej szczytowej części dachu nie opada ku ziemi, ale, wbrew prawom perspektywy geometrycznej, zmierza do nieba. (AZH)

Herbert nie tylko opisuje budynki znajdujące się na obrazie Avercampa, ale także stara się przeniknąć przez ściany jednego z domów. Pozwala w ten sposób zadziałać wyobraźni - widzi więcej, niż zostało namalowane. Znamienne, że w żadnej innej wersji nieukończonego eseju nie pojawia się fragment, w którym zagląda on do wnętrza domu. Czyżby uznał, że zbyt mocno pofolgował swojej fantazji? Rezygnuje także $\mathrm{z}$ animizacji zapisanej w formie wyliczenia oraz $\mathrm{z}$ wykorzystanej przy opisie domu nautycznej metaforyki. Co charakterystyczne, w relacjach często używa porównań i oddziałującego na zmysły obrazowania. Dalsza część następnego rękopisu jest dużo uboższa, a browar już nie przypomina „ciasta uciekającego z formy”, lecz „dzieło piekarza":

Po lewej stronie [patrzącego] rozłożysty browar ciepły jak bursztyn, z zaciekami czerwieni [cynobru] stający jakby trochę dęba malowany jakby na przekór zasadom perspektywy zbieżnej, jakby w swojej asymetrii [stając dęba, bo szczyt dachu oddalony od oka jest] [murkach przybudówkach] był dziełem piekarza raczej niż arehitekta [budowniczego]. (AZH)

W tym samym rękopisie, nieco dalej, odnajdujemy jeszcze jeden - trochę bardziej rozbudowany - wariant ekfrazy. Warto zauważyć, że pojawia się w nim nowe porównanie - dach domu, wcześniej utożsamiany z żaglem, przypomina teraz „czapkę na uszy":

Po lewej stronie [obrazu] [fragment] dom ze spadzistym dachem [spadzistym długim jak czapka na uszy] przybudówką, gankiem, schodkami dalej rozłożysty browar ciepły jak bursztyn z zaciekami czerwieni, malowany jakby na przekór zasadom perspektywy zbieżnej [i linii prostej] z nąáną niechęcią do linii prostej [nato- 
miast z wyraźną] a z predylekcją do krzywizn, łuków, asymetrii, tak że sprawia wrażenie bardziej dzieła piekarza niż architekta. (AZH)

Najbardziej lakoniczny opis rozwija Herbert w podobny, bardzo skrótowy sposób. Nie zrezygnował jedynie z porównania odziałującego na wyobraźnię zmysłową: „ciepły jak bursztyn”, które - podobnie jak „cynobrowa czerwień” - jest niebanalną próbą oddania kolorystyki płócien Avercampa:

po lewej stronie rozłożysty browar, ciepły jak bursztyn z zaciekami cynobrowej czerwieni. (AZH)

I wreszcie ekfraza pochodząca z wydanego maszynopisu, najbardziej dopracowana. Rozbudowana, ale nie do granic przesytu (jak w najdłuższym rękopisie):

Po lewej stronie istny bałagan form: ucięty ramą fragment domu z długim, spadzistym jak czapka na uszy dachem, obrośnięty niechlujnymi przybudówkami. Przylega do niego browar bursztynowo ciepły, z zaciekami czerwieni, rozłożysty, twór raczej piekarza niż architekta, malowany z wyraźną predylekcją do asymetrii, browar - rzekłbyś - stojący dęba, bo linia szczytowa budowli prowadzi do nieba ${ }^{35}$.

Wydaje się, że Herbert starał się skonstruować opis jak najprecyzyjniejszy, dlatego bardzo bogate, nadmiernie rozbudowane fragmenty, znajdujące się w rękopisie opatrzonym tytułem Malarz czwartej pory roku..., ujarzmiał, wygładzał. Zestawienia te pozwalają, w niewielkim choćby stopniu, uchwycić warsztat Herberta. Jego ćwiczenia $\mathrm{z}$ ekfrazy byłyby zatem poszukiwaniem formy wystarczająco pojemnej, ale nie upajaniem się nadmiarem. Poeta nie zrezygnował oczywiście z możliwości, jakie daje mu literacki opis, jednak nie absolutyzował go. Przeciwnie, podporządkował język malarskiemu przedstawieniu - ponieważ tekst ma posłużyć lepszemu wczuciu się w atmosferę płócien Avercampa, którego nie bez powodu na początku szkicu poeta dwukrotnie nazywa „malarzem rozkosznym” (AZH). Rozkosz obcowania ze sztuką Avercampa miałaby równać się rozkosznej uczcie literackiej, jaką pisarz szykował dla czytelnika. Pejzaż zimowy ze ślizgawka jest dla Herberta niezwykle ważny także dlatego, że staje się impulsem do podjęcia wyprawy w świat zimowych zwyczajów XVII-wiecznej Holandii.

35 Z. Herbert, De stomme van Kampen..., s. 46. 


\section{5. „Mały ekskurs w dziedzinę holenderskich obyczajów hibernalnych" ${ }_{36}$}

Herbert ubolewał nad tym, że stan badań nad życiem i twórczością Avercampa nie jest zbyt dobrze rozwinięty. Podkreślał, że gdy pracowal nad przygotowaniem eseju o „Niemowie z Kampen", istniała zaledwie jedna monografia ${ }^{37}$ poświęcona malarzowi. Poeta musiał zatem korzystać z innych prac dotyczących holenderskiego malarstwa złotego wieku lub - szerzej - ówczesnej kultury. Liczne notatki na temat dzieł Avercampa i bliskiej mu flamandzkiej tradycji malarstwa pejzażowego czy „lodowych” zwyczajów, świadczą o tym, że Herbert, zanim przystąpił do pisania eseju, przeprowadził gruntowne studia. Czytał książki z zakresu historii sztuki, a także - co za chwilę postaram się udowodnić - historii obyczajów:

W tym zimowym salonie można jednak odróżnić lud od zamożnych mieszczan. Ci ostatni ukazani w tradycyjnych czerniach i zdają się demonstrować, że raczej zamarzliby na śmierć niż pozbyli się [dobrze] skrojonego surduta i jedwabnych pończoch. Ludzie ubodzy mają ten jeden przywilej, że nie obowiązują ich konwenanse. „Prawdziwy Holender - zauważa jeden z podróżników - jest najdziwniejszą figurą pod słońcem. Nie nosi płaszcza, lecz siedem kamizelek i dziesięć par spodni. Na każdą parę spodni Holendra przypada 1 spódnica jego żony”. (AZH)

Passus dotyczący wielu warstw zimowych strojów Holendrów zaczerpnął Herbert z książki Paula Zumthora Życie codzienne w Holandii w czasach Rembrandta. Poeta cytuje go wielokrotnie, w jednym miejscu pozostawiając trop pozwalający ustalić, skąd pochodzi to przytoczenie - pojawia się odesłanie: „Zumthor 60" (AZH). Taki rodzaj podpowiedzi zdarza się niezwykle rzadko, najczęściej Herbert nie opisuje cytatów, zwykle też nie umieszcza ich w cudzysłowie, dlatego czasem trudno ustalić, czy zanotowana refleksja to słowa poety, czy może fragment ja-

${ }^{36}$ Cytaty rozpoczynające tę i ostatnią część artykułu pochodzą z Archiwum Zbigniewa Herberta.

37 „O Avercampie [...] pisano niewiele (jedna [tylko] monografia [z katalogiem rozproszonych po świecie dzieł])" (AZH). Herbertowi mogło chodzić o książkę C. Welcker, Hendrick Avercamp (1585-1634), bijgenaamd „De Stomme van Campen” en Barent Avercamp (1612-1679), "Schilders tot Campen”, Zwolle 1933 (wydanie uaktualnione C. Welcker, D.B. Hensbroek-van der Poel, Doornspijk 1979) lub o katalog wystawy: Hendrick Avercamp 1585-1634, Barent Avercamp 1612-1679. Frozen Silence. Paintings from museums and private collections, red. A. Blankert, Amsterdam-Zwolle 1982. 
kiegoś opracowania dotyczącego holenderskiego złotego wieku. W przypadku przywoływanej relacji ,jednego z podróżników” nie mamy jednak wątpliwości, z jakiego źródła czerpał poeta:

Niderlandczycy $[\ldots]$ walczą ze srogością zimy, nakładając jedną sztukę odzieży na drugą. Jest to cecha narodowa, charakterystyczna zwłaszcza dla ubioru ludzi ubogich. „Prawdziwy Holender - pisze Olivier Goldsmith - jest najdziwniejszą figurą pod słońcem... Nie nosi płaszcza, lecz siedem kamizelek i dziewięć par spodni, tak że uda zaczynają mu się prawie już w pachwinach... Na każdą parę spodni Holendra przypada jedna spódnica u jego żony" ${ }^{3}$. Na skutek podobnych praktyk sylwetka oczywiście traci na elegancji; odzież natomiast jest bardzo starannie utrzymana ${ }^{39}$.

Okazuje się, że nie tylko w tym miejscu Herbert korzystał z ustaleń Zumthora. Praca Życie codzienne w Holandii... stanowiła także inspirację przy pisaniu akapitów poświęconych sportom i zabawom zimowym oraz ich egalitarnemu chatakterowi. Teza mówiąca, że ślizgawki miały przypominać „demokratyczne rendez-vous wszystkich ze wszystkimi, bez różnicy kondycji, majątku, stanu i zawodu" (AZH) pojawia się również u Zumthora: „Sportem zimowym jest ślizgawka, tak często przedstawiana przez malarzy. [...] Młodzi i starzy, mężczyźni i kobiety, predykanci, urzędnicy, książęta - wszyscy spędzają dni na lodzie. W sportowym zapale odżywa wtedy corocznie, choć na krótko, dawna demokratyczna równość ludowa" ${ }^{40}$.

Oczywiście podobne spostrzeżenia znaleźć można również w innych pracach, których jednak Herbert nie mógł znać, ponieważ są to najczęściej książki wydane już po śmierci poety. W katalogu wystawy Holland Frozen in Time. The Dutch Winter Landscape in the Golden Age pogląd o demokratyczności XVII-wiecznych holenderskich zabaw na lodzie poparty jest słowami Hugo Grotiusa, holenderskiego prawnika, dyplomaty i filozofa, żyjącego na przełomie XVI i XVII w.:

Współcześni pisarze twierdzili, że lód był świetnym „wyrównywaczem”, w sensie eliminacji różnic klas i statusu społecznego. Hendrick Avercamp zawsze zaludniał swoje sceny lodowe przedstawicielami wszystkich warstw społeczeństwa. Od arystokracji, po

$3^{8}$ F. van Thienen, Das Kostüm der Blütezeit Hollands, Berlin 1930, s. 30.

39 P. Zumthor, Życie codzienne w Holandii w czasach Rembrandta, przeł.

E. Bąkowska, Warszawa 1965, s. 60.

40 Ibidem, s. 151. 
robotników niskiego stanu, każdy zabierany był na lód. Hugo Grotius (1583-1645) opisywał ten fenomen w następujący sposób:

Tutaj nikt nie pyta o rangę, tutaj wszyscy są swobodni i wolni,

Tutaj wiejska dziewka ma szlachciankę u swego boku,

Tam mój wiejski chłopak pędzi naprzód, prowadząc damy,

Gdzieś tam widzę towarzyszącego mieszczance dworzanina.

Nic na to nie poradzi ani wielki monarcha, ani żaden filozof,

Ktoś widzi pracę wilgoci zastygającej w lód.

Jeśli ktoś pyta z głębi serca, kto jest naprawdę mądry,

Wtedy mówię z głębi serca, naprawdę nikt, tylko lód ${ }^{4 \mathrm{I}}$.

Lód robił więcej ponad likwidowanie społecznych barier między ludźmi, pełna życia swoboda sprawiała, że serca zaczynały bić

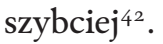

Herbertowi chodziło o jak najlepsze przybliżenie czytelnikowi ówczesnego kontekstu kulturalnego, obyczajowego. Nie dziwi więc ustalenie, że lista fragmentów, w których dostrzegamy wyraźny wpływ pracy Zumthora, jest dłuższa. Przywoływane przez Herberta „zawody z najsłynniejszą «Wędrówką jedenastu miast» (na trasie wynoszącej 200 kilometrów)" (AZH) opisuje szwajcarski badacz: „Organizowano też zawody, z których najważniejsze, słynna «Wędrówka jedenastu miast», mogły obejmować, w pomyślnych latach, trasę ponad 200 kilometrów" 43. Co ciekawe, szczegóły, które wydają się zaczerpnięte z książki Zumthora, Herbert zgromadził w jednym miejscu. Spójrzmy na jeszcze jeden cytat $\mathrm{z}$ pozostawionego $\mathrm{w}$ rękopisie nieukończonego eseju Malarz czwartej pory roku..., w którym poeta wylicza uczestników zimowych zabaw:

kupcy grający w KAFLA (coś pośredniego między golfem i hokejem), przezorni chłopi zaopatrzeni w długie drągi na przypadek załamania się lodu lub wpadnięcia w przeręble (takie dramaty są tu również przedstawione), bajecznie kolorowe sanie zaprzężone $\mathrm{w}$ konia $\mathrm{z}$ ozdobnym czaprakiem z dzwoneczkami. Nawet osoby wiekowe nie chcą odmówić sobie przyjemności zimy - siedzą godnie na wysokich krzesłach, doktórych przyczepione są łyżwy i służący służy za jest siłą napędową [do nóg krzeseł przypięte są łyżwy, służący stoi z tyłu, wprawia w ruch pojazd]. (AZH)

$4^{\mathrm{I}} \mathrm{J}$. Biusman, Duizend jaar weer, wind en water in de Lage Landen, t. 1, Franeker 2000, s. 252-253.

${ }^{42}$ Holland Frozen in Time..., s. 20.

43 P. Zumthor, op.cit., s. 152. 
Wszystkie informacje odnajdziemy oczywiście w Życiu codziennym w Holandii...:

Wśród tej ciżby dźwięczą dzwoneczki koni, które ustrojone w czapraki, z głowami w pióropuszach, ciągną sanie z malowanego drzewa. Na krzesłach, umocowanych na łyżwach, wozi się dzieci i starców. [...] Chłopi [...], jadąc na łyżwach, dźwigają czasem długą żerdź na ramieniu, ażeby podeprzeć się nią, gdy wpadną w jaką dziurę. [...] W ,pastorał”(kolf), podobny do nowoczesnego hokeja, grano w zimie na lodzie [...]; do palika, stanowiącego cel, rzucano małe drewniane piłki za pomocą zakrzywionych kijów ${ }^{44}$.

Herbert, podobnie jak Zumthor, stara się wytłumaczyć, co to takiego $\operatorname{colf}^{45}$. Słowo zapisuje na dwa różne sposoby: raz nazywa grę „kaflem”, natomiast w innym miejscu notuje „kalf - podobny do hokeja i golfa" (AZH).

Poeta zwraca uwagę nie tylko na przedstawione przez Avercampa zimowe rozrywki, ale też na towarzyszące im niebezpieczeństwa. Temat ten nie jest wcale marginalny. W monografii Avercampa poświęcono zagadnieniu podrozdział Cold, Discomfort and Danger ${ }^{4}{ }^{6}$. Podobne motywy są charakterystyczne nie tylko dla twórczości Avercampa. „Jak można zobaczyć na rycinie Rembrandta [Łyziwiarz] pochodzącej z roku około 1639, wielu łyżwiarzy miało ze sobą długi drąg, by - w razie gdyby załamał się pod nimi lód - mogli się wydostać" ${ }^{47}$. Herbert, doskonale przybliżający czytelnikowi XVII-wieczne zimowe obyczaje, wydaje się uważnym obserwatorem scen lodowych przedstawionych na płótnach Avercampa i skrupulatnym czytelnikiem opracowań poświęconych kulturze holenderskiej złotego wieku.

Pisarza interesowały także stroje ludzi bawiących się na lodzie. Zdawał sobie sprawę $\mathrm{z}$ tego, że dla pełniejszego poznania bogactwa pojawiających się u Avercampa postaci będzie „konieczna wycieczka w dziedzinę kostiumologii” (AZH). Dostrzegł śmieszność odmalowanych na lodzie figur, z góry odrzucał jednak hipotezę, że autor mógł dążyć do osiągnięcia efektu parodii. Przeciwnie, chciał traktować płótna Holendra jako przegląd ówczesnej mody:

44 Ibidem, s. 151-153.

45 Na ten temat zob. The Game of Colf, w: Holland Frozen in Time..., s. 26.

${ }^{6}$ P. Roelofs, The Paintings. The Dutch on the Ice, w: Hendrick Avercamp..., s. $70-74$.

47 Holland Frozen in Time..., s. 23. 
przedstawione figury [postacie] brodzące przez śnieg, ślizgające się po lodzie, nie są wcale [ani piękne, ani zgrabne] urodziwe [wydają się wręcz groteskowe], przypominają owady o grubych odwłokach [z których] i zabawnie chudych odnóżach. Ale tutaj konieczny jest mały ekskurs [kostiumologiczny], konieczny po to, aby udowodnić, że Avercamp nie był przedrzeźniał rodzaju ludzkiego i nie miał zacięcia karykaturzysty. (AZH)

Tą wyprawą w świat strojów jest - przytaczana za Zumthorem - opinia Goldsmitha o wielowarstwowym ubiorze Holendrów. Anegdota nie wyjaśnia wszystkiego. Wydaje mi się, że pełniejszą odpowiedź na nurtujące poetę kwestie z dziedziny „kostiumologii” przynosi artykuł Aspects of Costume. A Showcase of Early 17th-Century Dress, którego autorką jest Bianca M. du Mortier ${ }^{48}$. Badaczka przekonuje, jak ważnym kluczem interpretacyjnym okazują się stroje:

W XVII-wiecznym społeczeństwie klasowym ubrania były istotną oznaką warstwy - więcej - pozwalały współczesnym identyfikować nie tylko odmienną klasę społeczną, ale też określać wzajemnie materialny status, stan cywilny i zawód, jak również region lub miasto, a nawet wioskę, z której się pochodzi ${ }^{49}$.

Historycy sztuki zwracają uwagę na szczególne zamiłowanie do przedstawiania współczesnych strojów, które można potraktować jako jeden z dowodów na to, że nauczycielem Avercampa w trakcie jego pobytu w Amsterdamie był „portrecista i malarz historyczny” - Pieter Isaacsz. „Zdaje się, że wszystkim, co Avercampowi wszczepił Isaacsz, była troska o precyzyjnie obserwowane kostiumy" 5०. Rodzi się zatem pytanie, czy w upodobaniu do skrupulatnego oddania strojów i portretowania ówczesnych obyczajów można dopatrywać się podejścia, które obecnie nazwalibyśmy realistycznym?

Seymour Slive podkreśla:

Kiedy w odniesieniu do siedemnastowiecznych holenderskich pejzażystów rozważamy kwestię realizmu, ważne jest, by mieć na uwadze, że ci artyści prawie nigdy nie malowali swych obrazów „z natury”. Praktyka tworzenia w plenerze upowszechniła się dopiero

$4^{8}$ B.M. du Mortier, Aspects of Costume. A Showcase of Early 17th-Century Dress, w: Hendrick Avercamp..., s. 141-163.

49 Ibidem, s. 143.

5० Holland Frozen in Time..., s. 52. 
w dziewiętnastym wieku. Wcześniej pejzażyści prawie zawsze pracowali w swoim atelier" ${ }^{5}$.

Jak zatem pogodzić tezy o realizmie z faktem, że XVII-wieczne krajobrazy powstawały $\mathrm{w}$ pracowniach artystów? Dlaczego - jak pisze Herbert - Avercamp był „zaliczony do wczesnych [realistów]” (AZH)? Poeta dowodzi, że przedstawień „Niemowy z Kampen" nie należy traktować jako dokumentów historycznych. Na obrazach Holendra prawda miesza się ze zmyśleniem, nie wiemy, w którym miejscu kończy się rzeczywistość, a zaczyna rejon fantazji. Ulubionym obiektem rodzącym się w jego malarskiej wyobraźni był zamek: „mistrz Avercamp lubił zamki i zmyślał je ehętnie często ku strapieniu [rozpaczy] tych, którzy chcą ustalić topografię [dokładną topografię] bajki” (AZH). Herbert wskazuje na to, że niepowodzeniami muszą zakończyć się wszelkie próby dokładnego zlokalizowania wykreowanych przez artystę przestrzeni: „Zamek po lewej stronie zbudowany jest z błękitno-zielonych płytek lodu. Avercamp lubił zamki i [jak się zdaje] zmyślał je ku strapieniu tych, którzy chcą ustalić ścisłą topografię [topografię fantazji]" (AZH). Herbert nie stara się odszukać przyczyn tej zupełnie zaskakującej słabości Avercampa do zamków, skłonny jest widzieć w nich baśniowy element zimowego świata. Jest raczej uradowany niż zakłopotany ich obecnością:

Wędrując dalej w głąb obrazu widzimy po lewej i prawej stronie zabudowania i dziwaczny gotycki zamek. [...] Powiedzieliśmy „dziwny zamek". Iștọțịiẹ Avercamp malował zamki często, z upodobaniem i sam je wymyślał. Architektura obronna w Holandii należała do rzadkości, w kraju zupełnie płaskim takie kosztowne obiekty [kunsztowe (kosztowne) spiętrzenie kamieni] miały nikłe uzasadnienie strategiczne. Groźnie zznosząee się gớrę mury oswojone [spętane] zostały jak Guliwer siecią straganów, sklepów, namiotów, gdzie po trudach można pokrzepić siłę tęgim łykiem wódki jałowcowej. Avercamp lubił stawiać zamki w środku obrazu, na gładkim jak stół lodowisku. Przypominały [one] kunsztowny tort imieninowy [weselny]. (AZH)

Poeta odkrywa przed nami kolejne oblicze Avercampa artysty. Konstruowana przez malarza baśniowa topografia nie wyklucza jednak przekonania o realistycznej wizji świata, o głoszonej za pośrednictwem sztuki pochwale rzeczywistości. By jednak rozstrzy-

${ }^{1}$ S. Slive, Dutch Painting 1600-1800, New Haven-London 1995, s. 181. 
gnąć, jaki model reprezentacji Herbert odkrywa w twórczości Avercampa, trzeba wykorzystać kolejny pozostawiony przez poetę trop interpretacyjny - $\mathrm{w}$ punkcie piątym enigmatycznego planu eseju o „Niemowie z Kampen” określony jako „naiwność”.

\section{Naiwność, czyli „cnota pokory wobec rzeczywistości”}

Herbert planował jedną z części eseju poświęcić problemowi naiwności w malarstwie Avercampa. Pozostawione w rękopisie fragmenty szkicu zawierają duże partie tekstu, które uznać możemy za elementy podrozdziału dotyczącego naiwności. Powracają wówczas najczęściej trzy konteksty: opinia Francesca da Hollandy o malarstwie flamandzkim, którą Herbert odnosi do twórczości Avercampa ${ }^{52}$, koncepcja naiwności stworzona przez Friedricha Schillera oraz działalność „malarzy naiwnych”, spadkobierców twórczości Celnika Rousseau.

W części eseju, która zaplanowana została jako rozważania dotyczące specyficznie pojętej - jak się za chwilę przekonamy - naiwności Avercampa, najczęściej pojawia się odniesienie do fragmentu Dialogów rzymskich da Hollandy. Oto jeden z wariantów tego odwołania, pochodzący z najdłuższego rękopisu zatytułowanego Malarz czwartej pory roku...:

W wieku 16-tym [XVI] mieszkal [bawil] $[\mathrm{w}]$ Rzymie kawaler Francesco da HOLLANDA, Portugalczyk, który zajmował się sztuką, odwiedzał pracownie, rozmawiał z artystami, zaprzyjaźnił się nawet z samym Michałem Aniołem. Wyniki swoich studiów ogłosił w księdze pt. Dialogi w Rzymie, gdzie znajdujemy charakterystyczny, krótki fragment poświęcony malarstwu flandryjskiemu, co równie dobrze [dokładnie] dotyczy sztuki holenderskiej [XVII]. Kryteria nie uległy zmianie, opinie wobec czegoś, co odmienne wykazują zadziwiającą trwałość [jak wiara w duchy].

„We Flandrii maluje się po to, by zewnętrzny wzrok oszukać rzeczami, które się podobają, malują też stroje, architekturę, zieleń pól, cieniste drzewa, rzeki i mosty, i to, co nazywa się krajobrazem, a w nich żywo poruszające się figury. Choć to odpowiada niektórym oczom, naprawdę nie ma w tym ani rozumu, ani sztuki, ani symetrii, ani proporcji, ani wyboru, ani wielkości i, koniec końców, malarstwo to jest bez substancji i bez nerwu" ${ }^{33}$. (AZH)

52 „Teoretyk renesansowej sztuki Francesco da Hollanda [- co prawda wcześniejszy od A., ale jego słowa można odnieśćc” (AZH).

53 Herbert nie korzysta z polskiego thumaczenia tego fragmentu, autorstwa Lucjana Siemieńskiego: „We Flandrach ulubionemi są malowidła wyrachowane 
Da Hollanda wyraźnie dystansuje się od dokonań północnej szkoły malarstwa. Jej sposób naśladowania rzeczywistości jest dlań nie do przyjęcia, ponieważ artyści niderlandcy nie respektują klasycznych reguł sztuki. Zarzuty techniczne (dotyczące braku symetrii i selekcji, która doprowadzić ma do przedstawienia idealnego piękna, wadliwej perspektywy, podejmowania niskich tematów) wydają się nie do odparcia. Jednak konkluzja Portugalczyka budzi pewne zastrzeżenia. W innym fragmencie rękopisu odnajdujemy komentarz Herberta do słów da Hollandy:

Gniewna tyrada [da Hollandy] lepiej niż cokolwiek innego oddaje różnicę [niemożnośé] między sztuką Południa i szkołą Północy [między radosnym belcanto a mową żywiołów]. Różnice są istotnie duże Odmienność [Przepaśé] tych artystycznych światów jest [istotnie uderzająca ogromna wielka, że można zrozumieć tę różną ${ }^{54}$. Ale Hollanda w zacietrzewieniu palnął okropne głupstwo [odmawiając Holendrom], kiedy mówi, że malarstwo holenderskie jest bez substancji i nerwu. (AZH)

Poeta trafnie pokazuje, że podstawą oceny, jaką da Hollanda wystawia malarstwu flamandzkiemu, staje się wyznawana przez niego odmienna koncepcja sztuki. Portugalski teoretyk wyraźnie zafascynowany jest malarstwem szkoły południowej, tworzącej zgodnie z klasycznymi reguły sztuki, której przeciwstawia model północny i jawnie go deprecjonuje. Herbert nie stara się zdyskredytować tez da Hollandy, uznawszy niektóre z jego argumentów za słuszne. Nie może jednak zgodzić się na ostatnie stwierdzenie Portugalczyka. Podejrzewa, że jest ono wynikiem „Zacietrzewienia” i - sam równie zawzięty - stwierdza, że da Hollanda „palnął okropne głupstwo”. A skoro Herbert uznał wcześniej, że fragment Dialogów rzymskich z powodzeniem odnieść można do twórczości Avercampa, to również przykład ma-

na złudzenie oka; dlatego wybierają tam przedmioty wdzięczne lub takie, o których nie możesz nic złego powiedzieć, jak prorocy i święci. Zazwyczaj bywają tam rupiecie, chałupy, pola bardzo zielone $\mathrm{z}$ cienistemi drzewami, rzeki i mosty, zgoła krajobraz, z mnóstwem figur i tu i ówdzie; a chociaż to sprawia wrażenie na niektóre oczy, nie ma w tem ani rozumu, ani sztuki, ani żadnej symetryi, żadnej proporcyi, żadnego wyboru, ani cienia wielkości: słowem malowanie takie nie ma ani treści, ani siły”. F. da Hollanda, Dialogi rzymskie [fragm.], przeł. L. Siemieński, w: Teoretycy, pisarze i artyści o sztuce 1500-1600, wybór, oprac. J. Białostocki, Warszawa 1985, s. 179.

54 Być może cały ten fragment umieszczony przeze mnie w nawiasie kwadratowym Herbert przekreślił, jednak linia przebiega prawie na całej długości ponad tekstem. 
larstwa pejzażowego Holendra posłuży mu do odparcia zarzutu braku „substancji i nerwu”.

Herbert jest wyraźnie zadowolony z faktu, że Avercamp „nie mieści się w kategoriach wielkich przedstawień baroku" (AZH), co po raz kolejny pozwala mu dowieść odrębności malarza. Cieszy się, że historia sztuki nie kończy się na przykładach artystycznej doskonałości, opartej wyłącznie na władzy rozumu. Dlatego „wielkiemu Michałowi Aniołowi” przeciwstawia cudownie niedoskonałego Avercampa:

Ale jakaż to ulga - myślimy sobie, jak to dobrze - że obok wielkiego Michała Anioła, który twierdził o sobie, że maluje mózgiem, nie rękami [jakby to było możliwe], istnieje wspaniale mały Hendrick Avercamp, który lekceważący sobie symetrię, proporcje i nadętą wielkość [wzniosły temat].

Ten malarz pozwala organizować się światu [żyć światu] spontanicznie [tak, jak mu się podoba, swobodnie], tak jak nieuregulowanej rzece [wodom rzeki pełnej zakrętów i wirów]. Nie podszeptuje [stosuje] żadnyeh reguł [krępuje go sztywnymi, gotowymi reguła$\mathrm{mi}$ ] matematycznych. Jego perspektywa geometryczna [jest dziwaczna] może przyprowadzić o mdłości subtelne zmysły klasycystów. (AZH)

Herbert dowartościowuje wizję świata, którą wyczytuje z płócien Holendra. Chce widzieć w nich spontaniczną kreację rzeczywistości. To malarz jest podporządkowany regułom, jakie dyktuje świat, a nie odwrotnie - świat nie jest przedstawiany zgodnie z zasadami sztuki wyznawanymi przez artystę. W tym sensie „Niemowa z Kampen” okazuje się twórcą prostodusznym, czyli naiwnym. Przy poszukiwaniu odpowiedzi na pytanie, jak należy pojmować tę naiwność, przydatne okażą się fragmenty zapisków, w których Herbert przywołuje nazwisko Schillera oraz liczne odwołania do grupy „malarzy naiwnych”. Spójrzmy jednak najpierw na jedną z definicji naiwności, ukutą na potrzeby szkicu o Avercampie:

Kiedy myślę o Avercampie i kilku jeszcze starych mistrzach, wiem, że ich sztuka nie da się wyczerpać w kategoriach estetycznych. Koloryt, rysunek, perspektywa. Jest w nich cnota pokory wobec rzeczywistości i to, co obecnie nazywamy naiwnością, a przedtem nazywano czystością serca. (AZH)

Widzimy, że Herbert wyraźnie rozgranicza dwa sposoby rozumienia naiwności. Wyróżnia naiwność, którą postrzega jako 
technikę artystyczną, a więc coś wtórnego. Tej koncepcji przeciwstawia pojętą po staroświecku naiwność, oznaczającą wierność światu, pokorę, którą utożsamia z „czystością serca”, ze szczególnym rodzajem prostoty duszy. Dlatego w eseju o Avercampie możemy odnaleźć następujące stwierdzenie: „Podobnie jak większość niderlandzkich kolegów, został wierny niezmierzonym obszarom nieba i płaskiej ziemi, pociętej krętymi liniami wielu rzek, a także osobliwemu światłu swojej ojczyzny" (AZH). Słowa te przywodzą na myśl fragment Ceny sztuki ze zbioru Martwa natura z wędzidtem, w którym - w odniesieniu do malarstwa dawnych mistrzów, ich sposobu reprezentacji (równoznacznej z pochwałą) rzeczywistości - poeta używa określenia „naiwność":

Dawni mistrzowie, wszyscy bez wyjątku, mogli powtórzyć za Racine'em - „pracujemy po to, aby podobać się publiczności”, to znaczy, wierzyli w sens swojej pracy, możliwość międzyludzkiego porozumienia. Afirmowali widzialną rzeczywistość z natchnioną skrupulatnością i dziecięcą powagą, jakby od tego miały zależeć porządek świata i obroty gwiazd, trwałość niebieskiego sklepienia.

Niech pochwalona będzie ta naiwnośćs5.

Nieprzypadkowo Herbert, w kontekście pojęcia naiwności, powołuje się także na Schillera. Nie pada co prawda tytuł rozprawy niemieckiego pisarza, ale na podstawie notatek z Archiwum możemy stwierdzić, że Herbertowi chodziło o tekst O poezji naiwnej i sentymentalnej:

Naiwność jest dla Schillera wyrazem harmonii człowieka z otaczającą naturą, natura obejmuje także społeczeństwo. Ten prosty ideał życia posiadał antyk. Sentymentalizm oznacza świadomość trudnych do przezwyciężenia trudności, sprzeczności społecznych [- kontrastu ideału i rzeczywistości]. Naiwny = antyczny. Sentymentalny $=$ nowoczesny. $(\mathrm{AZH})$

Teza mówiąca o uległości Avercampa - artysty naiwnego - wobec świata zdaje się mieć źródło w myśli Schillera, który stwierdza:

Od naiwności wymaga się, ażeby natura odniosła zwycięstwo nad sztuką, bez względu na to, czy odniosła je bez wiedzy i wbrew woli

55 Z. Herbert, Cena sztuki, w: Martwa natura z wędzidtem, Warszawa 2003, s. 37 . 
danej osoby, czy z jej pełną świadomością. W pierwszym przypadku jest to naiwność zaskoczenia, która rozśmiesza; w drugim naiwność postawy i usposobienia, która wzrusza ${ }^{56}$.

Herbert przywołuje Schillerowską opozycję naiwności i sentymentalności ${ }^{57}$ po to, by udowodnić, że naiwność Avercampa jest anachronizmem, postawą człowieka z innej epoki. Zadaniem twórcy naiwnego jest wszak odtwarzanie tego, co istnieje:

w stanie naturalnej prostoty, gdy człowiek, wraz ze wszystkimi swoimi zdolnościami, działa jak harmonijna jedność i gdy tym samym jego natura w sposób pełny wyraża się w rzeczywistości, poeta musi widzieć swoje zadanie w możliwie doskonałym naśladowaniu rzeczywistości ${ }^{8}$.

W podobny sposób określa Herbert prostoduszną wizję świata wyczytaną z prac Avercampa. Ta prostota będąca - zgodnie z definicją poety - „cnotą pokory wobec rzeczywistości”, odpowiada Schillerowskiej koncepcji naiwności, równoznacznej $\mathrm{z}$ akceptacją świata, poddaniem się jego prawom, postrzeganiem siebie jako elementu natury. Twórczość Avercampa ma niewątpliwie charakter naiwny. W jego obrazach dostrzegamy - mówiąc słowami Schillera - „trzeźwy zmysł obserwacji i twarde trzymanie się zgodnego świadectwa zmysłów, a w aspekcie praktycznym zrezygnowane podporządkowanie się konieczności (ale nie ślepemu naciskowi) natury, czyli poddanie się temu, co jest i co być musi" 59 .

Herbert przestrzega jednak, by naiwności wyczytanej z dzieł Avercampa nie identyfikować z pracami „malarzy naiwnych”. Określenie „malarz naiwny” należy traktować jako rodzaj obelgi:

Nie byłoby wielkim komplementem azanie ge [przyznanie mu] pierwszym malarzem naiwnym, bo to z kolei budzi skojarzenia z międzynarodowym gangiem [mafią] spryciarzy, którzy smarują jakieś [farbkami skradzionymi z tornistrów uczniowskich] [to znaczy napełniają zmysły naiwnych szczęściem] karzełki pokraezne sceny mitologiczne pełne cukierkowych kolorów, czy też inne po-

${ }^{6}$ F. Schiller, O poezji naiwejej i sentymentalnej, przeł. I. Krońska, w: Dzieła wybrane, wybór, wstęp, oprac. S.H. Kaszyński, t. 1, Poznań 2006, s. 239.

57 „Poeta, jak już powiedziałem, albo jest naturą, albo będzie jej szukać. $\mathrm{W}$ pierwszym przypadku będzie poetą naiwnym, w drugim - sentymentalnym". Ibidem, s. 251. Schiller pisze przede wszystkim o poezji, jednak jego ustalenia z powodzeniem odnieść można również do malarstwa.

$5^{8}$ Ibidem, s. 251.

59 Ibidem, s. 284. 
twory tak cenione przez dyrektorów fabryk guzików i dyrektorów kas oszczędnościowych. (AZH)

Dlatego Herbert stara się zastąpić pojęcie naiwności innymi sformułowaniami:

Moją rozkosz w obcowaniu z Avercampem mąci przypuszczenie [obawa], że pewna „moda” [zainteresowanie] na jego twórczość [jaką można zaobserwować w ostatnich czasach] ma chyba związek z ożywioną działalnością kupiecką tzw. [tak zwanych] malarzy naiwnych. Przyznam się, że nie znoszę tej szkoły i podejrzewam ją o najgorsze instynkty. Ci, bądź co bądź dorośli, ludzie wyłudzają po prostu pieniądze, grając na niskich uczuciach - [ściślej] swojskości [przytulności] albo powrotów do utraconych rajów dzieciństwa. Bo jak inaczej rozumieć te infantylne landszafty, rzeczki, młyny, krowy na łące, las malowany dokładnie listek po listku lub zakochanych o twarzach potulnych matołów na tle parku i niebie z niebieskiej tafli, gdzie tkwi księżyc wielki jak dynia. Brzydkie to, infantylne i głupie. Jeśli Avercampa można nazwać „naiwnym”, to tylko w sensie odnalezionej harmonii człowieka z naturą, ale w tym przypadku [Avercampa] wolałbym użyć staroświeckich określeń, a mianowicie - czystość i prostota serca [wierzy w porządek rzeczy $\mathrm{i}$ harmonię człowieka $\mathrm{z}$ natura] . A to już jest cnota, a nie [artystyczna] metoda. (AZH)

Podstawowym zarzutem, jaki naśladowcom Celnika Rousseau stawia Herbert, jest sprzeniewierzenie się naturze. Ich malarstwo to nie wyraz harmonii z naturą, ale karkołomne próby powrotu do niej, poskromienia jej za pośrednictwem sztuki. Naiwność rozumieć należy w tym kontekście jako technikę artystyczną. Prostota nie jest - jak w przypadku Avercampa czystością serca, ale prostactwem i infantylnością. Poeta wysuwa ponadto argumenty estetyczne, pisze (bardzo pryncypialnie), że ich prace są po prostu „brzydkie” i - tu przechodzi do wartościowania - „głupie” ${ }^{60}$. Jest oczywiście świadomy subiektyw-

60 O tym, że „szajka” malarzy naiwnych wzbudzała szczególną niechęć Herberta, świadczy fakt, że poświęcił on wiele energii na to, by wyszydzić ich twórczość: „Avercamp chciał, by powiedzieć o nim malarz naiwny, ale to słowo zostało zrabowane (jak inne ważne słowa) i zawłaszczone przez międzynarodó [ową] szajkę fabrykantów obrazków, występujących pod szyldem «malarzy naiwnych». Powołują się [Wywodzą] oni na Théodore'a Rousseau Celnika [- jego sława polegała na] nie zdająe sobie sprawy, żejego sława polegała na jeg unikalności [tego zjawiska], jakby cichym danym nam przyrzeczeniu, że po nim nie będzie spadkobierców. Malarstwo wspaniałej «szkoły» udają dzieci, ale mają zupełnie dorosły pociąg do alkoholu, kobiet i pieniędzy - wiem, 
ności tych sądów, podkreśla nawet, że to jego punkt widzenia. Zrozumiałe staje się zatem, dlaczego słowo „naiwny” przywodzi na myśl złe skojarzenia. Pisarz proponuje więc, aby dla uniknięcia niewygodnych i mylących analogii sparafrazować je. Decyduje się „użyć staroświeckich określeń”, dużo trafniej charakteryzujących twórczość Avercampa, którego nieprzypadkowo nazwał „dziwaczną pomyłką chronologii” (AZH).

\section{MAGDALENA ŚNIEDZIEWSKA}

\section{"The Mute of Kampen" - Hendrik Avercamp in Zbigniew Herbert's Archives}

The present article analyses the rough drafts of Zbigniew Herbert's essay on Hendrik Avercamp - the seventeenth century Dutch landscape painter who specialized in winter landscapes and scenes with numerous tiny figures. The author attempts to reconstruct the compositional idea for the essay and establishes facts concerning the research work done by Herbert concerning the life and work of Avercamp, confronts the findings with the present state of research and considers the issue of the biographical dimension of the painter's artistic output as one of the keys to solving the interpretative problems of his paintings and the artistic tradition that had influenced the shaping of the Avercamp idiom of paintings. Avercamp's works are juxtaposed in the article with the landscapes painted by Pieter Bruegel the Elder to show the difference between the visions of the world represented by the two painters. Bruegel, in Herbert's opinion, is bitter in his reflection on the subject of transiency of human existence. Avercamp, conversely, tends to have a cheerful outlook on life, the world and his compatriots. Avercamp's paintings allow us to get to know winter customs of the Dutch, their winter outdoor games participated by all - hence a thesis posed by the poet underlying the democratic character of skating rinks. In doing so, Herbert proposes to scrutinize carefully Avercamp's artistic output within the context of, defined after Schiller, the notion of naivety, understood as "the virtue of accepting reality with humility" adopted from the old masters.

bo byłem na jednym z ich zlotów. Malują łaciate krowy na łące [soczystej] jak sałata łące pod niebem [o kolorze] używanej dawniej farbki do bielizny, po którym spacerują białe obłoki regularne jak pyknięcie $\mathrm{z}$ fajki, albo nastrojowy pejzaż o zmierzchu, na ławce matoł i matołkówna o tępo trzymają się za ręce, wzrok mają tępy nad sowa na drzewie, księżyc, w dali pałac, żółte okna” (AZH). Herbert błędnie podaje imię artysty uznawanego za ojca tego nurtu w sztuce. Malarzem naiwnym, którego przywołuje poeta, jest oczywiście Henri Rousseau (1844-1910), zwany Celnikiem, a nie Théodore Rousseau (1812-1867), XIX-wieczny pejzażysta stojący na czele Barbizończyków. 
MAgdalena ŚNIEDZIEWSKA - doktorantka w Zakładzie Literatury i Kultury Nowoczesnej Instytutu Filologii Polskiej UAM, autorka książki Wierność rzeczywistości. Zbigniew Herbert o postawie wobec świata i problemach jego reprezentacji (w druku). Pod opieką prof. Agaty Stankowskiej przygotowuje rozprawę doktorską Polska literatura powojenna wobec malarstwa bolenderskiego złotego wieku.

e-mail:magdasd@amu.edu.pl 
